\title{
Nutritional Composition of Staple Food Bananas of Three Cultivars in India
}

\author{
Santhosh Kumar Kookal1 ${ }^{1}$, Appachanda Thimmaiah ${ }^{2}$ \\ ${ }^{1}$ School of Biotechnology, National Institute of Technology, Calicut, India \\ ${ }^{2}$ Department of Sustainable Living, Maharishi University of Management, Fairfield, Iowa \\ Email: athimmaiah@mum.edu
}

How to cite this paper: Kookal, S.K. and Thimmaiah, A. (2018) Nutritional Composition of Staple Food Bananas of Three Cultivars in India. American Journal of Plant Sciences, 9, 2480-2493. https://doi.org/10.4236/ajps.2018.912179

Received: December 24, 2017

Accepted: November 23, 2018

Published: November 26, 2018

Copyright (c) 2018 by authors and Scientific Research Publishing Inc. This work is licensed under the Creative Commons Attribution International License (CC BY 4.0).

http://creativecommons.org/licenses/by/4.0/

Open Access

\begin{abstract}
Banana (Musa spp.) is an important ingredient of several dishes and its nutritional and other biochemical composition at different stages is yet to be scientifically studied. In the present study the most popularly cultivated species of Nendran, Nijali poovan and Robusta banana in Southern India are selected. Variations in the nutritional and biochemical compositions associated with ripened and unripened stages of banana fruits were studied. Proximate composition, mineral and phytochemical compositions of ripened and unripened banana flours were analyzed and the total soluble sugars in unripened banana range from 1.70 to $2.15 \mathrm{mg} / 100 \mathrm{~g}$ of the samples and that of ripened banana range from 37.5 to $43.8 \mathrm{mg} / 100 \mathrm{~g}$ of the samples. Mineral compositions show that they are rich sources of calcium, phosphorus and iron. In addition to this they are rich sources of antioxidant potential phytochemicals such as polyphenols, flavanoids, vitamin $\mathrm{C}$ and lesser in quantity of anti nutritional factors such as phytates and oxalates. The current study revealed the variations of biochemical compositions of three varieties in unripened and ripened stages. This will be useful for the exploitation of these crops to obtain and formulate the value added products.
\end{abstract}

\section{Keywords}

Plantain Crops, Biochemical Composition, Banana Flour, Proximate Analysis

\section{Introduction}

Banana is one of the most popular desert fruit, in terms of per capita consumption as well as the most widely traded fruit in the world. India is the largest producer of banana accounting for $17.8 \%$ of world share followed by Barzil [1].

Fruits and vegetables are rich sources of various health beneficial phytochem- 
icals, such as vitamins, minerals, carbohydrates, flavanoids and phenols [2]. Extensive researches on these phytochemicals by various groups have been revealed that they have immense role in the reduction of certain degenerative and malnutrition related diseases [3] [4] [5]. Banana is one of the most widely distributed and consumed fruit in the tropical and subtropical countries of the world [6]. Considering the nutritional aspects of banana, it is one of the world's leading food crops with rich sources of minerals, vitamins, carbohydrate, flavanoids and phenolic compounds [7] and it is one of the easily accessible economic fruit crops to common people. It can be consumed as cooked as well as in uncooked forms [8].

The development of new product is a strategic area at the food industry. Consumers demand foods mainly of two reasons, one in deal with the traditional nutritional aspects of foods, whereas the second feature is that the additional health benefits accepted from its regular ingestion and such kinds of food products are called nutraceutical foods [9]. India is the largest producer of banana, its share in the world trade is merging at present. Bulk of banana produced in the country is utilized in domestic market as fresh fruit but for a few processed products like chips. There is immense potential for processing banana into several value added products like dehydrated ripe banana jam, jelly, fruit bar, wine, vinegar, puree, baby food and pickle which can fetch profit both in the domestic as well as in the foreign market [10].

Banana fruits are rich source of nutrients and their biochemical composition varies with growth stage and maturity [11]. The study of nutritional status of the banana fruits will be useful for exploitation of the crop to obtain value added products. Therefore, the present work was undertaken to study the nutritional and biochemical compositions of three different varieties of ripened and unripened bananas such as Nendran, Nijali poovan and Robusta. The study emphasizes the nutritional and biochemical compositions of these varieties and their changes upon ripening.

\section{Materials and Methods}

\subsection{Preparation of Sample}

The ripe and unripe varieties of Musa AAA Spp. (Robusta), Musa AAB Spp. (Nendran) and Musa AB Spp. (Njali poovan) were collected from Kasaragod district of Kerala. The fresh ripe and unripe bananas were peeled, cut into thin slices and dried in an electric oven at $60^{\circ} \mathrm{C}$ for $12 \mathrm{~h}$. Dried samples were ground, sieved and stored at room temperature $\left(25^{\circ} \mathrm{C} \pm 2^{\circ} \mathrm{C}\right)$ in air tight containers and the powdered sample were used for the analysis of chemical compositions. The varieties of unripe banana are represented as Un-Nendran, Up-Njali poovan, Ur-Robusta and ripe banana varieties are represented as Rn-Nendran, Rp-Njali poovan and Rr-Robusta respectively.

\subsection{Chemical Analysis}

The moisture, ash and protein content in the samples were determined accord- 
ing to methods described in AOAC [12]. Total ash content in the sample was determined by ignition in muffle furnace at $550^{\circ} \mathrm{C}$ for $6 \mathrm{~h}$. The total protein in the sample was determined by using Biuret method [13]. The crude fat was determined using the Soxhlet extractor and the solvents used were chloroform and methanol according to Bligh and Dyer methods [14]. Crude fiber was estimated in the samples by following acid and alkali treatment methods according to AOAC [15]. Total soluble sugars were estimated by the methods of Dubois et al. [16]. Reducing sugars were estimated by method of Somogyi [17] and the amount of non reducing sugars was calculated as the difference between total soluble sugars and reducing sugars. Fructose content of the sample was estimated by the method of Ashwell [18].

The $\mathrm{pH}$ of the sample was determined by methods given by Berwal et al. [19]. $10 \mathrm{~g}$ of sample was weighed and it was macerated with $100 \mathrm{~mL}$ of deionized water. It was thoroughly mixed and the mixture was allowed to stand for $30 \mathrm{mi}-$ nutes. The supernatant was collected by centrifugation at $7863 \mathrm{~g}$ for $15 \mathrm{~min}$ using refrigerated centrifuge and the supernatant was decanted and determined the $\mathrm{pH}$. Vitamin C of samples was estimated by the method of Robinson and Scotz [20].

Phytic acid was determined by the method of Davis and Reid [21]. Finely ground samples $(1 \mathrm{~g})$ were extracted with $25 \mathrm{ml} 0.5 \mathrm{~N}$ nitric acid with continuous shaking on mechanical shaker (Roteck RRS-06) at $150 \mathrm{rpm}$ for 3 hours and subsequently filtered through Whatman no.1 filter paper. To $1 \mathrm{~mL}$ of the filtrates, $0.4 \mathrm{~mL}$ of distilled water and $1 \mathrm{~mL}$ of ferric ammonium sulphate were added and placed in water bath at $40^{\circ} \mathrm{C}$ for 20 minutes. After cooling down to room temperature $\left(27^{\circ} \mathrm{C}-30^{\circ} \mathrm{C}\right), 5 \mathrm{~mL}$ isoamyl alcohol was added. Immediately, after mixing the contents in the tubes, $0.1 \mathrm{~mL}$ ammonium thiocyanate solution was added. The tubes were shaken well and centrifuged at, $7863 \mathrm{~g}$ for 10 minutes $\left(4^{\circ} \mathrm{C}\right)$. After 15 minutes of incubation at room temperature $\left(27^{\circ} \mathrm{C}-30^{\circ} \mathrm{C}\right)$, absorbance was read at $465 \mathrm{~nm}$ against isoamyl alcohol blank. The extinction was inversely proportional to phytate concentration. For standard curve, different concentrations containing 80 to $200 \mu \mathrm{g} / \mathrm{mL}$ of phytic acid were taken and treated in the same way as samples. The phytic acid content was expressed as $\mathrm{mg} / 100 \mathrm{~g}$ of the sample.

Total phenolic contents were estimated with the Folin-Ciocalteu Reagent (FCR) colorimetric method [22], where $0.1 \mathrm{~mL}$ of sample extract was mixed with $0.2 \mathrm{~mL}$ of FCR. The contents were vortexes for $15-20$ seconds by using vortex mixture (Rotek vortex mixture: 1331). After 3 minutes, $2 \mathrm{~mL}$ of deionized water and $1 \mathrm{~mL}$ of saturated sodium carbonate solution was added to each tube and the reaction mixture was incubated for $2 \mathrm{hrs}$ at $37^{\circ} \mathrm{C}$. After incubation period the absorbance was measured at $765 \mathrm{~nm}$. Gallic acid standard was taken in different concentrations and treated similarly as the samples. Total phenolics are expressed as milligrams of gallic acid equivalent per $100 \mathrm{~g}$ of the sample.

Total flavanoids were estimated by the method of Marinova et al. [23]. Dried 
samples $(5 \mathrm{~g})$ were ground in $50 \mathrm{~mL}$ of deionized water in mortar and pestle. The mixtures were transferred to a conical flask and placed on rotary shaker at $150 \mathrm{rpm}$ for $12 \mathrm{hrs}$ to ensure full extraction. The mixtures were filtered and volume was made up to $50 \mathrm{~mL}$. To $1 \mathrm{~mL}$ aliquots of the sample extracts, $4 \mathrm{~mL}$ of deionized water and $0.3 \mathrm{~mL}$ of sodium nitrite were added. After 5 minutes of incubation at room temperature $\left(37^{\circ} \mathrm{C}\right), 0.3 \mathrm{~mL}$ aluminum chloride and $2 \mathrm{~mL}$ of $1 \mathrm{M}$ sodium hydroxide were added and total volume was made up to $10 \mathrm{~mL}$ with deionized water. The solution was mixed thoroughly and the absorbance was read at $510 \mathrm{~nm}$. For preparation of standard solution containing 20 to 100 $\mathrm{mg} / \mathrm{mL}$ catechin were taken and treated in the same way as samples. Total flavanoids content was expressed as milligram catechin equivalents per $100 \mathrm{~g}$ of the sample.

Oxalic acid was estimated by the method of Raghuramulu et al. [24]. $5 \mathrm{~g}$ finely ground samples were mixed with $100 \mathrm{~mL}$ of $2 \mathrm{~N}$ hydrochloric acid and the mixtures were shaken on a rotary shaker $150 \mathrm{rpm}$ for $2 \mathrm{hrs}$. The mixtures were boiled for 15 minutes, at $100^{\circ} \mathrm{C}$ and then cooled to room temperature $\left(37^{\circ} \mathrm{C}\right)$. To $25 \mathrm{~mL}$ of the filtrates, $5 \mathrm{~mL}$ of phosphoric tungstate reagent was added, stirred well and kept overnight at room temperature $\left(37^{\circ} \mathrm{C}\right)$. The following day, the filtrates were centrifuged at $7863 \mathrm{~g}$ for $15 \mathrm{~min}$ and filtered. To $20 \mathrm{~mL}$ of the filtrates, 2 or 3 drops of methyl red and neutralized with ammonia, $5 \mathrm{~mL}$ of calcium chloride buffer were added and stirred well. The mixtures were allowed to stand overnight. Next day, the mixtures were filtered through Whatman no. 40 paper. To the precipitates, $5 \mathrm{~mL}$ of $2 \mathrm{~N}$ sulphuric acid was added and heated at $80^{\circ} \mathrm{C}$ and titrated against $0.01 \mathrm{~N}$ potassium permanganate solutions (standardized with $0.01 \mathrm{~N}$ oxalic acid). The oxalic acid content was expressed as $\mathrm{mg} / 100 \mathrm{~g}$ of the sample.

Mineral compositions such as calcium, phosphorus and iron were estimated from acid digested samples. Reagents-diacid mixture: Nitric acid and perchloric acid were mixed in the ratio of 5:1. Finely ground samples $(1 \mathrm{~g})$ were taken in conical flask containing $25 \mathrm{~mL}$ diacid mixture and kept overnight. The following day, the samples were digested by heating till a clear white precipitate settled down at the bottom. The crystals were dissolved by the addition of deionized water. The contents were filtered through Whatman no.42 paper. Final volume was made up to $50 \mathrm{~mL}$ with deionized water and used for the determination of individual minerals.

Calcium in the digested solution was estimated by the method of Raghuramulu et al. [24]. An aliquot ( $1 \mathrm{~mL}$ ) of digested solution was pipette out into centrifuge tubes. A drop of methyl red indicator was added to the tubes till the solution turned light pink followed by the addition of few drops of liquid ammonia till the solution turned light yellow. A drop of glacial acetic acid was added to give a salmon pink color indicating the correct $\mathrm{pH}$ for the precipitation of the calcium. The contents were mixed well followed by the addition of $1 \mathrm{~mL}$ of ammonium oxalate solution and kept overnight. The following day, the tubes were centrifuged at $7863 \mathrm{~g}$ for $15 \mathrm{~min}$. The supernatants were discarded by inverting 
the tubes carefully on a clean filter paper. To the precipitates, $4 \mathrm{~mL}$ of liquid ammonia was added and centrifuged at $7863 \mathrm{~g}$ for $15 \mathrm{~min}$. The supernatants were discarded and the process was repeated 2 to 3 times. To the pellets, $10 \mathrm{~mL}$ of $1 \mathrm{~N}$ sulphuric acid was added and kept in boiling water bath $\left(100^{\circ} \mathrm{C}\right)$ till the contents started simmering and titrated against $0.01 \mathrm{~N}$ potassium permanganate (Standardized with $0.01 \mathrm{~N}$ oxalic acid). The end point was a definite pink color which persisted for at least 1 minute. The calcium content was expressed as $\mathrm{mg} / 100 \mathrm{~g}$ of the sample.

The iron content was estimated by the method of Raghuramulu et al. [24]. To $1 \mathrm{~mL}$ aliquots of solution, $1 \mathrm{~mL}$ of $30 \%$ sulphuric acid and $1 \mathrm{~mL}$ of potassium per sulphate were added and volume was made up to $8.5 \mathrm{~mL}$ with deionized water. To the above mixture, $1.5 \mathrm{~mL}$ of potassium thiocynate was added and allowed to stand for 20 minutes at room temperature $\left(37^{\circ} \mathrm{C}\right)$. The absorbance was measured at $540 \mathrm{~nm}$. For preparation of standard curve different volumes of working standard of iron solution were taken ranging from $0.5 \mathrm{~mL}$ to $3.5 \mathrm{~mL}$ corresponding to 0.5 to $3.5 \mu \mathrm{g} / \mathrm{mL}$. The iron content was expressed as $\mathrm{mg} / 100 \mathrm{~g}$ of the sample.

Phosphorous content was estimated by the method of AOAC [15]. To $1 \mathrm{~mL}$ aliquots of digested solution, $5 \mathrm{~mL}$ of $10 \%$ trichloroacetic acid, $1 \mathrm{~mL}$ of ammonium molybdate and $1 \mathrm{~mL}$ of metol were added. The tubes were allowed stands for 30 minutes at room temperature $\left(37^{\circ} \mathrm{C}\right)$ and absorbance read at $540 \mathrm{~nm}$. For preparation of standard curve different volumes of working standard solutions were taken ranging from 0.05 to $0.4 \mathrm{~mL}$ corresponding to 2.5 to $20.0 \mu \mathrm{g} / \mathrm{mL}$ of inorganic phosphorous. The phosphorous content was expressed as $\mathrm{mg} / 100 \mathrm{~g}$ of sample.

\subsection{Statistical Analysis}

Experiments were carried out in three replicates and presented as means \pm standard deviation of three replicates. One way ANOVA was carried out to examine whether the difference in the chemical components present in the different samples were significant or not. SPSS software (version 17) was used for the analysis.

\section{Result and Discussion}

\subsection{Dehydration Details of Banana}

Three different varieties of unripened and ripened bananas were dried separately in an electric oven at $60^{\circ} \mathrm{C}$ for $12 \mathrm{hrs}$. It was observed that $100 \mathrm{gm}$ of fresh ripened banana subjecting to oven drying yielded Rn (37.5 g), Rp (30.22 g) and Rr $(24.5 \mathrm{~g})$ respectively (Table 1$)$. However, unripened banana varieties yielded Un (45.14 g), Up (39.78 g) and Ur (30.6 g) respectively. It was observed that, the unripened oven dried bananas weighed more than the ripened oven dried banana varieties. This could be due to higher content of proto-pectin in unripened fruit which gets converted to pectin as the fruit ripened [25]. 


\subsection{Chemical Composition of Banana}

\subsubsection{Proximate Composition}

The result of the proximate composition of the three different varieties of unripened and ripened bananas are given in Table 2.

The moisture content was ranged from $39.40 \%$ to $60.06 \%$ in unripened and $66.23 \%$ to $75.25 \%$ in ripened banana respectively. The bananas generally contain $60 \%-68.6 \%$ of moisture as they ripen; it gradually increases from $68.6 \%-78.1 \%$ [26]. Increase in the moisture content during ripening might be due to carbohydrate breakdown, softening the tissue texture and osmotic transfer from the peel to pulp [27] [28] [29]. The ash content in the samples was shown that increased with ripening compared to unripened banana. There were varied changes in the mineral composition of bananas during ripening and the ash content increased with ripening [30] [31]. In Un, Up and Ur the ash content ranged from 1.55 to $1.90 \mathrm{mg} / 100 \mathrm{~g}$ of the sample and that of the $\mathrm{Rn}, \mathrm{Rp}$ and $\mathrm{Rr}$ was 1.61 to 2.22 $\mathrm{mg} / 100 \mathrm{~g}$ respectively. Khawas et al. [32] reported that ash content of banana fruits shows variations, which may be due to the differential absorption capacity of minerals at different stages of fruit development.

Table 1. Dehydration of banana $\left({ }^{\circ} \mathrm{C}\right)$.

\begin{tabular}{cc}
\hline \multirow{2}{*}{ Sample $(100 \mathrm{~g})$} & Oven drying $\left(60^{\circ} \mathrm{C}\right.$ for $\left.12 \mathrm{~h}.\right)$ \\
\cline { 2 - 2 } & $\mathrm{Wt}(\mathrm{g})$ \\
\hline $\mathrm{U}_{\mathrm{n}}$ & 45.14 \\
$\mathrm{R}_{\mathrm{n}}$ & 37.50 \\
$\mathrm{U}_{\mathrm{p}}$ & 39.78 \\
$\mathrm{R}_{\mathrm{p}}$ & 30.22 \\
$\mathrm{U}_{\mathrm{r}}$ & 30.60 \\
$\mathrm{R}_{\mathrm{r}}$ & 24.50 \\
\hline
\end{tabular}

$\mathrm{U}_{\mathrm{n}}$-Unripened Nendran, Rn-Ripened Nendran, Up-Unripened Njali poovan, Rn-Ripened Njali poovan, Ur-Unripened Robusta, $\mathrm{Rr}-$ Ripened Robusta.

Table 2. Proximate composition of banana.

\begin{tabular}{ccccccc}
\hline Samples & Un & Rn & Up & Rp & Ur & Rr \\
\hline Moisture content (\%) & $54.86 \pm 0.29$ & $66.23 \pm 0.26$ & $60.06 \pm 0.13$ & $70.53 \pm 0.48$ & $39.40 \pm 0.39$ & $75.25 \pm 0.20$ \\
Ash (mg/100g) & $1.55 \pm 0.04$ & $1.61 \pm 0.02$ & $1.90 \pm 0.07$ & $2.22 \pm 0.04$ & $1.66 \pm 0.06$ & $2.07 \pm 0.02$ \\
Proteins $(\mathbf{g} / \mathbf{1 0 0 g})$ & $2.00 \pm 0.41$ & $3.75 \pm 0.20$ & $2.25 \pm 0.20$ & $4.95 \pm 0.04$ & $1.75 \pm 0.20$ & $3.25 \pm 0.20$ \\
Lipids (g/100g) & $1.63 \pm 0.30$ & $1.77 \pm 0.66$ & $1.38 \pm 0.11$ & $0.66 \pm 0.05$ & $2.51 \pm 0.32$ & $2.59 \pm 0.04$ \\
Crude fiber (g/100g) & $4.03 \pm 0.06$ & $1.58 \pm 0.03$ & $2.30 \pm 0.08$ & $1.85 \pm 0.04$ & $2.78 \pm 0.02$ & $2.42 \pm 0.04$ \\
Total soluble sugars $(\mathrm{g} / \mathbf{1 0 0 g})$ & $1.80 \pm 0.04$ & $37.50 \pm 0.40$ & $2.15 \pm 0.04$ & $43.80 \pm 0.65$ & $1.70 \pm 0.08$ & $40.50 \pm 0.40$ \\
Fructose (g/100) & $0.415 \pm 0.004$ & $9.15 \pm 0.12$ & $0.477 \pm 0.002$ & $11.50 \pm 0.08$ & $0.49 \pm 0.01$ & $11.95 \pm 0.12$ \\
Reducing sugars $(\mathrm{g} / \mathbf{1 0 0 g})$ & $0.68 \pm 0.05$ & $16.75 \pm 0.20$ & $1.31 \pm 0.05$ & $18.15 \pm 0.02$ & $0.56 \pm 0.08$ & $19.12 \pm 0.10$ \\
Non reducing sugars $(\mathrm{g} / \mathbf{1 0 0 g})$ & $1.11 \pm 0.01$ & $20.75 \pm 0.20$ & $0.84 \pm 0.01$ & $25.30 \pm 0.85$ & $1.12 \pm 0.13$ & $21.37 \pm 0.31$ \\
\hline
\end{tabular}


The protein content shows that a significant difference among the Njali poovan and Robusta variety $1-2.5 \mathrm{~g} / 100 \mathrm{~g}$ present in unripened and ripened fruits. A gradual increase was observed under ripening condition $(3-4.95 \mathrm{~g} / 100 \mathrm{~g})$ of $\mathrm{Rn}, \mathrm{Rp}$ and $\mathrm{Rr}$. The protein content of banana fruit varied from mature fruit ( $1 \%$ to $2.5 \%$ ) to ripened fruit ( $3.8 \%$ to $4.2 \%$ ) depending up on genome type, variety, altitude and climatic conditions [33] [34] [35].

The lipid content ranges from $0.66-2.59 \mathrm{~g} / 100 \mathrm{~g}$ in ripened fruits, whereas in unripened fruits it ranges from $1.38-2.51 \mathrm{~g} / 100 \mathrm{~g}$. Banana's with low lipid and high energy contents make them very useful for the manufacturing of low fat diet formulations [36].

\subsubsection{Carbohydrate Composition}

The crude fiber content was highest in unriped fruits $(2-4 \mathrm{~g} / 100 \mathrm{~g})$ compared to ripened fruits $(1-2.42 \mathrm{~g} / 100 \mathrm{~g})$. The food value of crude fiber is greater, which helps to regulate certain physiological functions. The highest crude fiber content was observed in unriped nendran banana $(4 \mathrm{~g} / 100 \mathrm{~g})$. The crude fiber composition of unriped banana was observed to be high and it later dropped at the ripened stage [37]. The low fiber level of banana can be used for fortifying the weaning food. However, those fruits with high fiber content are desirable in adult diet, which are known to aid digestion, prevent constipation, help to the excretion of wastes and toxins from the body and also prevent colon cancer [38] [39].

The total soluble sugar content shows highest in ripened stage (37 - 43.8 $\mathrm{g} / 100 \mathrm{~g})$ compared to unripened banana $(1.7-2 \mathrm{~g} / 100 \mathrm{~g})$. Increase of total soluble sugars while ripening is an important trait of hydrolysis of starch into soluble sugars such as glucose, sucrose and fructose [29] [40] [41]. The fructose content in the unripened banana flour was ranging from $0.4 \mathrm{~g}$ to $0.5 \mathrm{~g} / 100 \mathrm{~g}$, whereas in the ripened samples ranging from $9 \mathrm{~g}$ to $11.95 \mathrm{~g} / 100 \mathrm{~g}$ of the samples. Reducing and non reducing content was highest in ripened fruits than unripened banana fruits (Table 2). In terms of the total carbohydrate contents of banana was high in the ripened stage, may be due to the high level of sugar, starch and dietary fibers [42].

\subsubsection{Mineral Composition}

Banana contains rich sources of mineral nutrients and it could serve as mineral element supplement in diet for both humans and animals [26] [40]. Mineral nutrients such as Calcium, phosphorus and Iron content of the ripened and unripened banana samples are given in Table 3 .

The observed value of $\mathrm{Ca}(\mathrm{mg} / 100 \mathrm{~g})$ in unripened banana samples ranged from $23.04 \mathrm{mg}$ to $38.57 \mathrm{mg} / 100 \mathrm{~g}$, whereas in ripened fruits ranging from $31 \mathrm{mg}$ to $52.6 \mathrm{mg} / 100 \mathrm{~g}$ of the samples. The calcium content was highest in ripened Robusta fruits $(52.6 \mathrm{mg} / 100 \mathrm{~g})$.

Phosphorus in Un, Up, Ur was found to be $34.37,56.25$ and $50 \mathrm{mg} / 100 \mathrm{~g}$ respectively. In $\mathrm{Rn}, \mathrm{Rp}$ and $\mathrm{Rr}$ samples it was shown to be 75, 81.25 and 78.13 $\mathrm{mg} / 100 \mathrm{~g}$ respectively. An increase in the phosphorus content was observed upon 
ripening. Morton [26] was reported a slightly high phosphorus value in ripened banana fruits (93 - $94 \mathrm{mg} / 100 \mathrm{~g})$. The phosphorus content was highest in ripened Njali poovan banana fruits $(81.25 \mathrm{mg} / 100 \mathrm{~g})$.

The iron content of the samples Un, Up and Ur showed 1.25, 1.25 and 1 $\mathrm{mg} / 100 \mathrm{~g}$ respectively. Whereas, in $\mathrm{Rn}, \mathrm{Rp}$ and $\mathrm{Rr}$ was $1.5,1.75$ and $1 \mathrm{mg} / 100 \mathrm{~g}$ respectively. In comparison $\mathrm{Ur}$ and $\mathrm{Rr}$, contains same amount of iron (1 $\mathrm{mg} / 100 \mathrm{~g}$ ) whereas, the unripened and ripened Nendran and Njali poovan varieties showed slight increase in their iron content during their maturation stage. The gradually increasing in the mineral contents of banana fruits during ripening stages is already reported [43].

\subsubsection{Phytochemical Composition of Banana}

Polyphenols are the biggest group of phytochemicals found in plant based foods and the structure of natural polyphenols varies from simple molecules to highly polymerized compounds. Majority of polyphenols existed as glycosides with different sugar units and acylated sugars at different positions of the polyphenol skeletons [44]. Banana peel represents about $40 \%$ of total weight of the fresh fruit [45]. The total amount of phenolic compounds in banana peel has been reported from 0.9 - $3 \mathrm{~g} / 100 \mathrm{~g}$ dry weight [46] [47]. The phytochemical composition of unripe and ripe banana variety $\mathrm{mg} / 100 \mathrm{~g}$ is presented in Table 4 . The polyphenol content in the sample Un, Up and Ur are 400, 431.25 and 506.25 $\mathrm{mg} / 100 \mathrm{~g}$ of samples. Whereas in $\mathrm{Rn}, \mathrm{Rp}$ and $\mathrm{Rr}$ showed 600, 625 and 725 $\mathrm{mg} / 100 \mathrm{~g}$ respectively. The present study showed an increase in polyphenol content during ripening. Newilah et al. [48] was studied in the increasing levels of

Table 3. Mineral composition of banana (mg/100g).

\begin{tabular}{cccc}
\hline Sample & Calcium & Phosphorus & Iron \\
\hline $\mathrm{U}_{\mathrm{n}}$ & $23.04 \pm 1.63$ & $34.37 \pm 2.55$ & $1.25 \pm 0.00$ \\
$\mathrm{R}_{\mathrm{n}}$ & $31.06 \pm 0.81$ & $75.00 \pm 5.10$ & $1.50 \pm 0.20$ \\
$\mathrm{U}_{\mathrm{p}}$ & $27.05 \pm 0.81$ & $56.25 \pm 0.00$ & $1.25 \pm 0.00$ \\
$\mathrm{R}_{\mathrm{p}}$ & $41.08 \pm 0.81$ & $81.25 \pm 5.10$ & $1.75 \pm 0.00$ \\
$\mathrm{U}_{\mathrm{r}}$ & $38.57 \pm 0.40$ & $50.00 \pm 0.00$ & $1.00 \pm 0.20$ \\
$\mathrm{R}_{\mathrm{r}}$ & $52.60 \pm 0.41$ & $78.13 \pm 2.55$ & $1.00 \pm 0.20$ \\
\hline
\end{tabular}

Table 4. Phytochemical composition of unripe and ripe banana variety $\mathrm{mg} / 100 \mathrm{~g}$.

\begin{tabular}{cccccc}
\hline Samples & Polyphenols & Flavonoids & Vitamin C & Phytates & Oxalates \\
\hline $\mathrm{U}_{\mathrm{n}}$ & $400.00 \pm 20.41$ & $112.00 \pm 0.81$ & $0.73 \pm 0.01$ & $0.088 \pm 0.04$ & $2.95 \pm 0.04$ \\
$\mathrm{R}_{\mathrm{n}}$ & $600.00 \pm 20.40$ & $115.00 \pm 0$ & $0.72 \pm 0.01$ & $0.077 \pm 0.01$ & $2.15 \pm 0.04$ \\
$\mathrm{U}_{\mathrm{p}}$ & $431.25 \pm 45.92$ & $118.00 \pm 0$ & $0.66 \pm 0.012$ & $0.0375 \pm 0.0004$ & $2.90 \pm 0.08$ \\
$\mathrm{R}_{\mathrm{p}}$ & $625.00 \pm 40.82$ & $110.50 \pm 0.40$ & $0.67 \pm 0.01$ & $0.0315 \pm 0.0004$ & $3.15 \pm 0.04$ \\
$\mathrm{U}_{\mathrm{r}}$ & $506.25 \pm 15.30$ & $131.00 \pm 0.81$ & $0.55 \pm 0.01$ & $0.0377 \pm 0.0002$ & $3.15 \pm 0.04$ \\
$\mathrm{R}_{\mathrm{r}}$ & $725.00 \pm 20.41$ & $126.00 \pm 20.41$ & $0.54 \pm 0.004$ & $0.3175 \pm 0.0002$ & $2.77 \pm 0.02$ \\
\hline
\end{tabular}


total polyphenol content in the ripe pulp compared to the green pulp of all plantain and cooking banana cultivars. Among the three varieties of ripe and unripe banana $\mathrm{Ur}$ and $\mathrm{Rr}$ showed a high values of polyphenols (506.25 $\mathrm{mg}$ and 725 $\mathrm{mg} / 100 \mathrm{~g}$ ). Whereas, the other two varieties ranged from $400-431.52 \mathrm{mg} / 100 \mathrm{~g}$ to $600-625 \mathrm{mg} / 100 \mathrm{~g}$ as they ripened. The total polyphenol composition of the banana cultivars are determined by their genetic factors and could have been modified by oxidative reactions during storage. Many of the phenolic compounds of the banana are being both good browning substrates and good antioxidants [49].

The flavanoids content of the samples Un, Up and Ur are 112, 118 and 131 $\mathrm{mg} / 100 \mathrm{~g}$ respectively and that of $\mathrm{Rn}, \mathrm{Rp}$ and $\mathrm{Rr}$ are $115,110.5$ and $126 \mathrm{mg} / 100 \mathrm{~g}$ respectively. In all the analyzed samples the flavanoids content shows that decreasing order from unripened banana to ripened fruit, except in the Nendran banana sample (Un-112mg and Rn-115mg). Fathemeh et al. [50] reported that the higher level of flavanoids in unripe banana than ripe banana fruit. The variation in the flavanoids content among different plant materials might be attributed to factors such as natural chemical composition, maturity at harvest, soil state and conditions of post harvest storage [51].

Vitamin $\mathrm{C}$ is an anti-oxidant and it acts as a good scavenger of several reactive oxygen species [52]. The value of vitamin $\mathrm{C}$ of samples ranged from $0.5-0.73$ $\mathrm{mg} / 100 \mathrm{~g}$ in unripened banana and that of ripened fruits ranging from 0.54 to $0.72 \mathrm{mg} / 100 \mathrm{~g}$ respectively. Fresh green banana is reported as a good source of vitamin C, but almost $65 \%$ of it is lost when made into flour [53].

Phyticacid is a natural plant inositolhexaphosphate commonly found in seeds and represents the principle form of stored phosphate [54]. Phytic acid forms complexes with proteins (Protein-Phytate complex) and chelates essential dietary minerals such as $\mathrm{Fe}, \mathrm{Zn}, \mathrm{Cu}$ and $\mathrm{Mg}$ thus decrease their utilization [55]. The phytate content of analyzed unripened banana samples was ranging from 0.037 to $0.08 \mathrm{mg} / 100 \mathrm{~g}$, whereas 0.031 to $0.317 \mathrm{mg} / 100 \mathrm{~g}$ in ripened banana fruits. Adeniji et al. [56] reported the low level of phytate content of musa hybrids between $1.2 \times 10^{-5}$ to $11.0 \times 10^{-5}$.

The oxalate content of sample Un, Up and Ur was ranging from 2.90 to 3.15 $\mathrm{mg} / 100 \mathrm{~g}$ of samples, whereas in ripened fruits $\mathrm{Rn}, \mathrm{Rp}$ and $\mathrm{Rr}$ ranged from 2.15 to $3.15 \mathrm{mg} / 100 \mathrm{~g}$. The oxalate content ranged from $0.64 \%-0.88 \%$ for several plantain and banana cultivars [53] [56].

\subsection{5. $\mathrm{pH}$ of the Samples}

Table 5 shows the $\mathrm{pH}$ of unripened and ripened banana fruit samples. The unripened banana samples such as Un, Up and Ur the pH ranged from 5.78 - 5.92. Whereas, the $\mathrm{pH}$ of $\mathrm{Rn}, \mathrm{Rp}$ and $\mathrm{Rr}$ was ranging from 4.50 to 4.63 respectively. The lower $\mathrm{pH}$ of ripened banana flour is may be due to the activity of enzymes such as amylase, glycosidase, phosphorylase, sucrose synthase and invertase on the degradation of starch and the formation and accumulation of soluble sugars [57] [58] [59] [60]. 
Table 5. $\mathrm{pH}$ of ripe and unripe banana varieties.

\begin{tabular}{cc}
\hline Sample & $\mathrm{pH}$ \\
\hline $\mathrm{U}_{\mathrm{n}}$ & $5.97 \pm 0.016$ \\
$\mathrm{R}_{\mathrm{n}}$ & $4.50 \pm 0.08$ \\
$\mathrm{U}_{\mathrm{p}}$ & $5.78 \pm 0.06$ \\
$\mathrm{R}_{\mathrm{p}}$ & $4.63 \pm 0.04$ \\
$\mathrm{U}_{\mathrm{r}}$ & $5.92 \pm 0.02$ \\
$\mathrm{R}_{\mathrm{r}}$ & $4.55 \pm 0.040$ \\
\hline
\end{tabular}

\section{Conclusion}

The present study reveals that the nutritional compositions are affected by various growth stages of banana. The findings of this study indicate that the ripening effects on the proximate composition, mineral contents, phytochemical content and anti-nutrients factors of the flours. The moisture content, total soluble sugars, crude protein, ash, $\mathrm{Ca}, \mathrm{P}, \mathrm{Fe}$ and $\mathrm{pH}$ of the samples increased with ripening stages. The crude fiber contents of the flours decrease with increasing the ripening process. The levels of oxalate and phytate in all the samples were low and may not hinder the bioavailability of essential nutrients in the flours. The results revealed that the nutritional quality of unripened and ripened banana flour helps to understand the chemical changes associated with ripening may form the basis for expanding the utilization of bananas to various food products. Exploration of antioxidant potential of the unripened and ripened banana flour will help to know the nutraceutical benefit of these varieties. The outcome of this research will help the food industry to optimize the nutritional compositions while designing new products that utilize the banana varieties discussed in the paper.

\section{Acknowledgements}

Support received from Department of Sustainable Living, Maharishi University of Management, Fairfield, Iowa is gratefully acknowledged. The Authors are grateful to School of Biotechnology, National Institute of Technology, Calicut, India for their help.

\section{Conflicts of Interest}

The authors declare no conflicts of interest regarding the publication of this paper.

\section{References}

[1] FAO (2002) FAO Statistical Data Bases. http://www.faostat.org

[2] Craig, W. and Beck, L. (1999) Phytochemicals. Health Protective Effects. Canadian journal of Dietetic practice and Research, 60, 78-84.

[3] Southon, S. (2000) Increased Fruit and Vegetable Consumption with in EU: Potential Health Benefits. Food Research International, 33, 211-217. 
https://doi.org/10.1016/S0963-9969(00)00036-3

[4] Atmoni, D., Chaher, N., Berboucha, M., Debbache, N. and Bondaoud, H. (2009) Flavanoids in Human Health: From Structure to Biological Activity. Current Nutrition and Food Science, 5, 225-237. https://doi.org/10.2174/157340109790218049

[5] Sampath Kumar, K.P., Bhowmik, D., Duraivel, S. and Umadevi, M. (2012) Traditional and Medicinal Uses of Banana. Journal of Pharmacognosy and Phytochemistry, 1, 51-63.

[6] Mohammad, Z.I. and Saleha, A. (2011) Musa paradisiaca L. and Musa sapientum L. A Phytochemical and Pharmacological Review. Journal of Applied Pharmaceutical Science, 1, 14-20.

[7] Singh, R., Kaushik, R. and Gosewade, S. (2018) Bananas as Underutilized Fruit Having Huge Potential as Raw Materials for Food and Non-Food Processing Industries: A Brief Review. The Pharma Innovation Journal, 7, 574-580.

[8] Merlene, A.B., Suriyakalu, M.A. and Gothandown, K.M. (2012) Varietal Impact on Phyto Chemical Contents and Antioxidant Properties of Musa accuminata (Banana). Journal of Pharmaceutical Science and Research, 4, 1950-1955.

[9] Brouns, F., Kettlitz, B. and Arrigoni, E. (2002) Resistant Starch and the Butyrate Revolution. Trends in Food Science and Technology, 13, 251-261. https://doi.org/10.1016/S0924-2244(02)00131-0

[10] Mary, Evelin, A., John, Jacob, P. and Vijayanand, D. (2007) Packaging and Storage Studies on Spray Dried Ripe Banana Powder under Ambient Conditions. Journal of Food Science Technology, 44, 16-21.

[11] Emaga, T.H., Robert, C., Ronkart, S.N., Wathelet, B. and Paquot, M. (2008) Dietary Fiber Components and Pectin Chemical Features of Peels during Ripening in Banana and Plantain Varieties. Bioresource Technology, 99, 4346-4354. https://doi.org/10.1016/j.biortech.2007.08.030

[12] AOAC (2010) Association of Official Analytical Chemists Official Methods of Analysis of the Association of Official Analytical Chemists. 18th Edition, AOAC International, Washington DC.

[13] Sadasivam, S. and Manickam (2008) A Biochemical Method. 3rd Edition, New Age International Publishers, New Delhi.

[14] Bligh, E. and Dyer, W. (1959) A Rapid Method of Total Lipid Extraction and Purification. Canadian Journal of Biochemistry and Physiology, 37, 911-917. https://doi.org/10.1139/y59-099

[15] AOAC (1995) Official Methods of Analysis. 16th Edition, Association of Official Analytical Chemists, Washington DC.

[16] Dubois, M., Gilles, K.A., Ton, J.K.H., Rebers, P.A. and Smith, F. (1956) Colorimetric Method for Determination of Sugars and Related Substances. Analytical Chemistry, 28, 350-356. https://doi.org/10.1021/ac60111a017

[17] Somogyi, M. (1952) Notes on Sugar Determination. Journal of Biological Chemistry, 195, 19-23.

[18] Ashwell, G. (1957) In: Colowick, S.J. and Kaplan, N.O., Eds., Methods in Enzymol 3, Academic Press, New York, 75.

[19] Berwal, J.S., Kapoor, C.M., Grewal, R.B. and Grag, M.K. (2004) Practical Methods in Food Analysis. 211-233.

[20] Robinson, W.B. and Scotz, E. (1945) The Indophenoxylene Extraction Method for Ascorbic Acid and Modifications for Interfering Substances. Journal of Biological Chemistry, 160, 217-225. 
[21] Davis, C.D. and Reid, H. (1979) An Evaluation of Phytate, Zinc, Copper, Iron and Manganese Content and Availability from Soya Based Extruded Vegetable Protein, Meat Substitute or Meat Extruders. British Journal of Nutrition, 41, 579. https://doi.org/10.1079/BJN19790073

[22] Singleton, V.L. and Rossi, J.A. (1965) Colorimetric Analysis of Total Phenolics with Phoshomolybdic-Phosphotungstic Acid Reagents. American Journal of Enology and Viticulture, 16, 144-158.

[23] Marinova, D., Ribarova, F. and Atanassova, M. (2005) Total Phenolics and Total Flavanoids in Bulgarian Fruits and Vegetables. Journal of the University of Chemical Technology and Metallurgy, 40, 255-260.

[24] Raghuramulu, N., Madhuvan, N.K. and Kalyanasundharam, S. (2003) A Manual of Laboratory Techniques. National Institute of Nutrition KMR, Hyderabad, 319-320.

[25] Tapre, A.R. and Jain, R.K. (2012) Study of Advanced Maturity Stages of Banana. International Journal of Advanced Engineering Research and Studies, 1, 272-274.

[26] Morton, J.F. (1987) Fruits of Warm Climates. Proceedings of the 6th National Symposium on Creating Markets for Economic Development of New Crops and New Uses, Miami, 29-46.

[27] John, P. and Marehal, J. (1995) Ripening and Bio-Chemistry of the Fruit. In: Gowens, Ed., Banana and Plantains, Chapna and Hal, London, 434-467.

[28] Onwuka, G.I. and Onwuka, N.D. (2005) The Effects of Ripening on the Functional Properties of Plantain and Plantain Based Cake. International Journal of Food Properties, 8, 347-353. https://doi.org/10.1081/JFP-200059489

[29] Sakyi-Dawson, E., Asamoah-Bonti, P. and Annor, G.A. (2008) Biochemical Changes in New Plantain and Cooking Banana Hybrids at Various Stages of Ripening. Journal of the Science of Food Agriculture, 88, 2724-2729. https://doi.org/10.1002/jsfa.3399

[30] Bieri, J.G., Stoewsand, G.S., Briggs, G.M., Phillips, R.W., Woodard, J.C. and Knapka, J.J. (1997) Report of the American Institute of Nutrition Adhoc Committee on Standards for Nutritional Studies. Journal of Nutrition, 107, 1340-1348.

[31] Adeyemi, O.S. and Oladiji, A.T. (2009) Compositional Changes in Banana (Musa sp) Fruits during Ripening. African Journal of Biotechnology, 8, 858-859.

[32] Khawas, P., Das, A.J., Dash, K.K. and Deka, S.C. (2014) Thin-Layer Drying Characteristics of Kachkal Banana Peel (Musa ABB) of Assam, India. International Food Research Journal, 21, 975-982.

[33] Von Loeiecke, H. (1950) Bananas. Inter Science Publishers, New York, 189.

[34] Lustre, A.O., Soriano, M.S., Morya, N.S., Balagot, A.H. and Tunac, M.M. (1976) Physico Chemical Changes in "SABA" Bananas during Normal and Acetylene Induced Ripening. Food Chemistry, 1, 125-132. https://doi.org/10.1016/0308-8146(76)90004-2

[35] Akaninwor, J.O. and Sodge, M. (2005) The Effect of Storage on the Nutrient Composition of Some Nigerian Foodstuffs: Banana and Plantain. Journal of Applied Sciences and Environmental Management, 9, 9-11.

[36] Gasster, M. (1963) The Banana in Geriatric and Low-Calorie Diets. Geriatrics, 18, 782.

[37] Egbebi, A.O. and Bademosi, T.A. (2012) Chemical Compositions of Ripe and Unripe Banana and Plantain. International Journal of Tropical Medicine and Public Health, 1, 1-5.

[38] Ayoola, P.B. and Adeyeye, A. (2009) Proximate Analysis and Nutrient Evaluation of 
Some Nigerian Pawpaw Seeds Varieties. Science Focus, 14, 554-558.

[39] Obiageli, O.A., Izundu, A.I., Ikeyi, A.P. and Ukamaka, O.G. (2016) Proximate Compositions of Fruits of Three Musa Species at Three Stages of Development. Journal of Dental and Medical Sciences, 15, 107-117.

[40] Stover, R.H. and Simmonds, N.W. (1987) Classification of Banana Cultivars. In: Stover, R.H. and Simmonds, N.W., Eds., Bananas, Wiley, New York, 97-103.

[41] Offor, C.E., Ugwu, P.C., Okechukwu, P.M. and Igwenyi, I.O. (2015) Proximate and Phytochemical Analyses of Terminalia catappa Leaves. European Journal of Applied Sciences, 7, 9-11.

[42] Rodríguez-Ambriz, S.L., Islas-Hernández, J.J., Agama-Acevedo, E., Tovar, J. and Bello-Pérez, L.A. (2008) Characterization of a Fiber-Rich Powder Prepared by Liquefaction of Unripe Banana Flour. Food Chemistry, 107, 1515-1521. https://doi.org/10.1016/j.foodchem.2007.10.007

[43] Ahenkora, K.M., Kye, A., Marfo, K. and Banful, B. (1997) Nutritional Composition of False Horn Apantu Pa Plantain during Ripening and Processing. African Crop Science Journal, 5, 243-248.

[44] Bravo, L. (1998) Polyphenols; Chemistry, Dietary Sources, Metabolism and Nutritional Significance. Nutrition Reviews, 56, 317-333. https://doi.org/10.1111/j.1753-4887.1998.tb01670.x

[45] Anhwange, B.A., Vgye, T.J. and Nyioatagher, T.D. (2008) Chemical Composition of Musa Sapientum (Banana) Peels. Electronic Journal of Environmental Agricultural and Food Chemistry, 8, 437-442.

[46] Someya, S., Yoshiki, Y. and Okubo, K. (2002) Antioxidant Compounds from Bananas (Musa Cavandish). Food Chemistry, 79, 351-354. https://doi.org/10.1016/S0308-8146(02)00186-3

[47] Nguyen, M.H. and Price, W.E. (2007) Air-Drying of Banana: Influence of Experimental Parameters, Slab Thickness, Banana Maturity and Harvesting Season. Journal of Food Engineering, 79, 200-207. https://doi.org/10.1016/j.jfoodeng.2006.01.063

[48] Newilah, N.G., Brat, P., Tomekpe, K., Alter, P., Fokon, E. and Etow, F.X. (2010) Effect of Ripening on Total Polyphenol Contents of Musa Hybrids and Cultivars Grown in Cameroon. Acta Horticulturae, 879, 413-418. https://doi.org/10.17660/ActaHortic.2010.879.45

[49] Robards, K., Prenzler, P.D., Tucker, G., Swatsitang, P. and Glover, W. (1999) Phenolic Compounds and Their Role in Oxidative Processes in Fruits. Food Chemistry, 66, 401-436. https://doi.org/10.1016/S0308-8146(99)00093-X

[50] Fatemeh, S.R., Saifullah, R., Abbas, F.M.A. and Azhar, M.E. (2012) Total Phenolics, Flavanoids and Antioxidant Activity of Banana Pulp and Peel Flours. Influence of Variety and Storage of Ripeness. International Food Research Journal, 19, 1041-1046.

[51] Huang, Q., Ou, B. and Prior, R.L. (2005) The Chemistry behind Antioxidant Capacity Assay. Journal of Agricultural and Food Chemistry, 53, 1841-1856. https://doi.org/10.1021/jf030723c

[52] Halliwell, B. (1987) Oxidants and Human Diseases: Some New Concepts. FASEB Journal, 1, 358-364. https://doi.org/10.1096/fasebj.1.5.2824268

[53] Suntharalingam, S. and Ravindran, G. (1993) Physical and Biochemical Properties of Green Banana Flour. Journal of Plant Foods for Human Nutrition, 43, 19-27. https://doi.org/10.1007/BF01088092 
[54] Hegeman, C.E. and Grabau, E.A. (2001) A Novel Phytase with Sequence Similarity to Purple Acid Phosphatases Is Expressed in Cotyledons of Germinating Soybean Seedlings. Plant Physiology, 126, 1598-1608. https://doi.org/10.1104/pp.126.4.1598

[55] Cheryan, M. (1980) Phytic Acid Interactions in Food Systems. Critical Reviews in Food Science and Nutrition, 13, 297-335. https://doi.org/10.1080/10408398009527293

[56] Adeniji, T.A., Sanni, L.O., Barimala, I.S. and Hart, A.D. (2007) Anti-Nutrients and Heavy Metals in Some New Plantain and Banana Cultivars. Nigerian Food Journal, 25, 171-177. https://doi.org/10.4314/nifoj.v25i1.33666

[57] Terra, N.N., Garcia, E. and Lajolo, F.M. (1983) Starch-Sugar Transformation during Banana Ripening: The Behavior of UDP Glucose Pyrophosphorylase, Sucrose Synthetase and Invertase. Journal of Food Science, 48, 1097-1100. https://doi.org/10.1111/j.1365-2621.1983.tb09169.x

[58] Emaga, T.H., Andrianaivo, R.H., Wathelet, B., Tchango, J.T. and Paquot, M. (2007) Effects of the Stage of Maturation and Varieties on the Chemical Composition of Banana and Plantain Peels. Food Chemistry, 103, 590-600. https://doi.org/10.1016/j.foodchem.2006.09.006

[59] Abbas, F.M., Alkarkhi, R.b.S., Yeoh, Y.S. and Azhar, E.M. (2010) Physico Chemical Properties of Banana Peeled Flours Influenced by Variety and Stage of Ripeness. Multi Variate Statistical Analysis. Asian Journal of Food and Agro-Industry, 3, 349-362.

[60] Singh, R., Ranvir, S. and Madan, S. (2017) Comparative Study of the Properties of Ripe Banana Flour, Unripe Banana Flour and Cooked Banana Flour Aiming towards Effective Utilization of These Flours. International Journal of Current Microbiology and Applied Sciences, 6, 2003-2015.

https://doi.org/10.20546/ijcmas.2017.608.239 